\title{
STANDARISASI EKSTRAK TERPURIFIKASI DAUN MANGGA ARUMANIS (Mangifera indica L.)
}

\author{
Dewi Andini Kunti Mulangsri", Elya Zulfa, Sugar Arifin dan Masduki Faqih \\ Fakultas Farmasi, Universitas Wahid Hasyim Semarang \\ J1. Menoreh Tengah X/22 Sampangan, Semarang 50236 \\ *Email : andini@unwahas.ac.id
}

\begin{abstract}
Abstrak
Ekstrak etanol daun mangga arumanis perlu dilakukan standarisasi untuk menjamin konsistensi mutu, keamanan dan efek yang dihasilkan. Purifikasi ekstrak dilakukan untuk menghilangkan adanya zat ballast yang tidak dapat menghasilkan efek terapi. Tujuan dari penelitian ini untuk memperoleh dan mengetahui hasil standarisasi ekstrak terpurifikasi daun mangga arumanis (ETDMA). Daun mangga arumanis disari dengan metode maserasi, pelarut etanol 96\%, dilanjutkan purifikasi ekstrak dengan metode ekstraksi cair-cair menggunakan pelarut air panas-etilasetat. Standarisasi ETDMA dilakukan untuk parameter spesifik dan nonspesifik. Parameter spesifik meliputi uji organoleptis, kadar senyawa larut air dan larut etanol. Parameter nonspesifik meliputi kadar air, kadar abu total, kadar abu tidak larut asam dan uji cemaran logam. Data standarisasi dianalisis secara deskriptif yang beberapa dibandingkan dengan standar yang telah ditetapkan. Hasil uji parameter spesifik berupa ekstrak terpurifikasi daun mangga arumanis kental berwarna hijau kecoklatan, kadar senyawa larut air dan etanol masing-masing sebesar 22\% dan 67,4\%. Hasil uji parameter nonspesifik berupa kadar air, susut pengeringan tidak memenuhi syarat, sedangkan kadar abu, kadar abu tidak larut asam, cemaran Pb dan Cd, cemaran mikroba memenuhi syarat. Jadi belum dapat dikatakan ekstrak terpurifikasi daun mangga arumanis terstandar.
\end{abstract}

Kata kunci : Daun mangga arumanis, Mangifera indica L., Ekstrak terpurifikasi, Standarisasi

\section{PENDAHULUAN}

Tanaman mangga arumanis (Mangifera indica L.) memiliki kandungan senyawa fenol (Hermansyah, 2015), selain itu terkandung senyawa alkaloid, tannin, terpenoid, antrakuinon, asam amino, flavonoid, saponin, kardiak glikosida dan resin (Diso et al., 2017; Ningsih et al., 2017) serta klorofil (Sumenda dkk., 2011).

Daun mangga arumanis mengandung resin dan klorofil, yang mana kedua zat tersebut merupakan zat ballast (Pramono, 2002). Penelitian sebelumnya telah membuktikan bahwa zat ballast yaitu klorofil dalam daun sirih secara tidak langsung akan mempengaruhi kemampuan dari aktivitas antibakterinya. Hasil dari penelitian ini, ekstrak terpurifikasi daun sirih hijau pada konsentrasi 2,5 $\mathrm{mg} / \mathrm{mL}$ memiliki aktivitas antibakteri, ditunjukkan terbentuknya zona hambat dengan diameter $7,01 \mathrm{~mm}$ (Widyaningtias, 2014). Hal ini menandakan bahwa dilakukannya purifikasi dengan menghilangkan zat ballast tidak mempengaruhi aktivitas antibakteri. Selain itu pada penelitian sebelumnya, purifikasi ekstrak dari bee propolis bertujuan untuk mendapatkan kandungan flavonoid lebih besar (Puspitasari dan Pramono 2015).
Tanaman mangga dapat diperoleh dari hasil budidaya pada lokasi tumbuh tertentu. Sumber dan lokasi tempat tumbuh dapat mempengaruhi variasi kandungan kimia dan efek yang akan dihasilkan. Umur dan masa panen yang berbeda juga dapat mempengaruhi variasi kandungan kimia dan efek yang akan dihasilkan. Standarisasi diperlukan untuk mengatasi kekomplekkan dari faktor-faktor tersebut. Konsistensi mutu, keamanan dan efek terapi yang dihasilkan dapat terjamin melalui standarisasi. Standarisasi dilakukan terhadap ekstrak baik ekstrak kasar maupun terpurifikasi. Parameter dalam standarisasi yang dilakukan berupa parameter spesifik dan non spesifik.

Berdasarkan latar belakang tersebut maka perlu dilakukan standarisasi dari ekstrak terpurifikasi daun mangga arumanis (ETDMA).

\section{METODOLOGI}

Daun mangga arumanis di determinasi di Laboratorium Biologi MIPA UNDIP Semarang. Daun mangga arumanis yang akan digunakan berasal dari kecamatan Sukorejo Kendal. Daun mangga arumanis yang sudah dipetik disortasi untuk mendapatkan daun dengan warna hijau tua dan kondisi tidak busuk. Daun mangga arumanis yang sudah disortasi selanjutnya dilanjutkan dengan pencucian pada air yang 
mengalir. Daun mangga arumanis yang telah bersih dilanjutkan dengan proses pengeringan. Pengeringan ini dilakukan dengan menggunakan oven pada suhu $50^{\circ} \mathrm{C}$. Serbuk simplisia kemudian disimpan dalam wadah tertutup rapat hingga dilakukan proses ekstraksi.

Sebanyak 1400 gram serbuk simplisia dimaserasi menggunakan pelarut etanol 96\%, perbandingan yang digunakan 1:10. Lamanya proses maserasi dan remaserasi total 5 hari. Maserat kemudian diuapkan pelarutnya dengan alat Rotary evaporator (RE) pada suhu $55^{\circ} \mathrm{C}$ sampai diperoleh ekstrak etanol daun mangga arumanis (EEDMA) yang kental.

Sebanyak 20 gram EEDMA diaduk dengan $400 \mathrm{ml}$ air panas sampai warna air berubah, didiamkan dan disaring. Total EEDMA yang digunakan untuk purifikasi 235 gram. Filtrat hasil penyaringan kemudian dimasukkan ke corong pisah dan ditambahkan dengan etil asetat (1:1) kemudian dikocok selama 1 menit (Puspitasari dan Pramono, 2015). Fase etil asetat yang ada di bagian atas dipisahkan dna fase air diulangi lagi sampai 4 kali. Fase etil asetat yang sudah ditampung kemudian diuapkan pelarutnya dengan alat RE pada suhu $50^{\circ} \mathrm{C}$ sampai diperoleh fase etil asetat yang kental yang disebut ekstrak terpurifikasi daun mangga arumanis.

Standarisasi parameter spesifik yang diujikan sebagai berikut :

a. Parameter Spesifik

Identitas ekstrak, Penetapan organoleptic dan uji kadar senyawa yang terlarut dalam air dan etanol 96\% (Depkes RI, 2000).

b. Parameter Nonspesifik

Kadar air, susut pengeringan, kadar abu, kadar abu tidak larut asam, cemaran logam $(\mathrm{Pb}$ dan $\mathrm{Cd})$ dan cemaran mikroba mengikuti metode pada buku Parameter Standar Umum Ekstrak Tumbuhan Obat (Depkes RI, 2000).

Analisis data hasil uji standarisasi parameter spesifik dan non spesifik dilakukan secara deskriptif. Parameter non spesifik dibandingkan dengan acuan.

\section{HASIL DAN PEMBAHASAN}

Hasil determinasi tanaman memastikan kebenaran tanaman yang digunakan dalam penelitian ini adalah mangga arumanis (Mangifera indica L.).

Ekstrak etanol daun mangga arumanis (EEDMA) yang berwarna hijau kehitaman diperoleh sebanyak 273,5 gram dengan rendemen ekstrak 19,54\%. Ekstrak terpurifikasi daun mangga arumanis (ETDMA) yang berwarna hijau kecoklatan diperoleh sebanyak 50,66 gram dengan rendemen $21,56 \%$.

Hasil uji parameter spesifik terdiri dari identitas ekstrak, organoleptis, kadar senyawa larut air dan larut etanol. Identitas ekstrak yaitu ekstrak terpurifikasi daun mangga arumanis (Mangifera indica L.) dengan karakteristik organoleptis berupa konsistensi kental, warna hijau kecoklatan dan bau tidak khas. Kadar senyawa larut air dan etanol secara berurutan sebesar $22 \%$ dan $67,4 \%$.

Kadar senyawa yang larut etanol lebih besar daripada kadar senyawa larut air. Hal ini menggambarkan bahwa kandungan senyawa yang kepolarannya semipolar lebih besar daripada senyawa bersifat polar. Senyawa yang bersifat semi polar sampai nonpolar akan larut dalam etanol, sedangkan senyawa yang bersifat polar akan larut dalam air (Saifudin dkk, 2011).

Kadar senyawa larut etanol disini menggambarkan senyawa semipolar yang tersari dari pelarut etil asetat (sebagai pelarut purifikasi ekstrak) namun terlarut dalam pelarut etanol, sehingga kadar senyawa larut etanol akan menjadi tinggi karena pelarut etanol sendiri dapat melarutkan senyawa semipolar juga. Senyawa-senyawa yang dapat tersari dalam pelarut etil asetat adalah polifenol, flavonoid, saponin, terpenoid dan antrakuinon (Handayani dkk, 2013; Marliana dan Saleh, 2011). Senyawa-senyawa itulah yang kemungkinan terkandung dalam ekstrak terpurifikasi daun mangga arumanis.

Pada kadar senyawa yang larut air lebih kecil dibandingkan kadar senyawa larut etanol. Hal ini menggambarkan senyawa polar yang terkandung dalam ETDMA jumlahnya sedikit. Senyawa polar pada uji kadar senyawa larut air dapat diperoleh kadarnya walaupun sampel yang diujikan adalah ekstrak terpurifikasi dengan pelarut etil asetat, hal ini menggambarkan bahwa pelarut etil asetat masih dapat menyari senyawa polar.

Hasil uji parameter non spesifik terdiri dari kadar air, susut pengeringan, kadar abu, kadar abu tidak larut asam, cemaran logam $(\mathrm{Pb}$ dan Cd) dan cemarang mikroba (angka lempeng total dan kapang dan khamir). Hasil uji parameter non spesifik ditunjukkan pada Tabel I. 
Tabel I. Hasil Uji Parameter Non Spesifik Ekstrak Terpurifikasi Daun Mangga Arumanis

\begin{tabular}{|c|c|c|c|}
\hline Perlakuan & Hasil & Syarat & Ket. \\
\hline Kadar air & $19,76 \%$ & $<10 \%^{\circ}$ & TMS \\
\hline Susut pengeringan & $6,28 \% \pm 0,633$ & $3-5 \%{ }^{*}$ & TMS \\
\hline Kadar abu & $0,07 \%$ & $<10 \%$ & MS \\
\hline Kadar abu tidak larut asam & $0,07 \%$ & $<1 \%^{\circ}$ & MS \\
\hline Cemaran logam $\mathrm{Pb}$ & $<0,01 \mathrm{mg} / \mathrm{kg}$ & $<0,01 \mathrm{mg} / \mathrm{kg} \cdots$ & MS \\
\hline Cemaran logam Cd & $<0,01 \mathrm{mg} / \mathrm{kg}$ & $<0,01 \mathrm{mg} / \mathrm{kg} \ldots$ & MS \\
\hline Angka lempeng total (ALT) & $<1 \times 10^{1}$ koloni/gram & $\leq 10^{6} \mathrm{koloni} / \mathrm{gram}{ }^{\prime}$ & MS \\
\hline 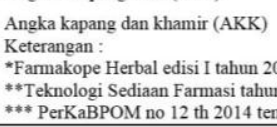 & $\begin{array}{l}<1 \times 10^{1} \text { koloni/gram } \\
09 \text { (Anonim, 2009) } \\
1994 \text { (Voight, 1994) } \\
\text { tang Persyaratan Mutu }\end{array}$ & $\leq 10^{4}$ koloni/gram ${ }^{\cdots}$ & MS \\
\hline
\end{tabular}

Hasil uji kadar air dan susut pengeringan ETDMA tidak memenuhi syarat. Sehingga ETDMA belum dapat dikatakan terstandar. Kadar air pada suatu ekstrak dapat menjadi tinggi dikarenakan faktor penyimpanan ekstrak yang belum baik. Kadar air yang tidak memenuhi syarat dimana di atas batas normal, dikhawatirkan akan menyebabkan tumbuhnya mikroba seperti jamur/kapang dan lama simpannya menjadi rendah (Yulianti dkk, 2014). Mikroba yang tumbuh pada ekstrak bahan alam akan menyebabkan penurunan mutu ekstrak.

Pada uji kadar senyawa larut etanol diperoleh kadar yang cukup tinggi yaitu 67,4\%. Walaupun susut pengeringan tidak memenuhi syarat, tidak membuat kadar senyawa larut etanol banyak yang hilang. Namun hal ini masih perlu dilakukan pengujian lanjutan misal seperti uji aktivitas farmakologinya, agar dapat diketahui senyawa yang telah hilang tersebut berpengaruh terhadap aktivitas farmakologinya atau tidak.

Parameter nonspesifik seperti kadar abu, abu tidak larut asam, cemaran logam $\mathrm{Pb}$ dan $\mathrm{Cd}$, cemaran mikroba (ALT dan AKK) ETDMA telah memenuhi syarat. Artinya cemaran-cemaran logam dan mikroba tidak mencemari ETDMA sehingga ETDMA dapat dikatakan berkualitas. Namun karena kadar air masih tinggi yaitu $>10 \%$ sehingga beresiko untuk ditumbuhi kapang maupun terjadi reaksi enzimatis dalam proses penyimpanan yang dapat mempengaruhi kualitas ekstrak (Saifudin dkk., 2011).

\section{UCAPAN TERIMAKASIH}

Peneliti mengucapkan terimakasih yang sebesar-besarnya kepada Kemenristekdikti karena penelitian ini dibiayai melalui Penelitian Dosen Pemula (PDP).
DAFTAR PUSTAKA

Anonim, 2009, No 261/MENKES/SK/IV/2009

Tentang Farmakope Herbal edisi I, Depkes RI, 2000, Parameter Standar Umum Ekstrak Tumbuhan Obat, Dirjen POM: Depkes RI

Diso, S U., Ali, M., Mukhtar, S I., and Garba, M., 2017, Antibacterial Activity and Phytochemical Screening of Mangifera indica (Mango) Stem and Leaf Extracts on Clinical Isolates of Methicillin Resistant Staphylococcus aureus, Journal of Advances in Medical and Pharmaceutical Sciences, 13 (1): 1-6.

Handayani, N., Fitriana, A., dan Handayani, S., 2013, Identifikasi dan Uji Aktivitas Antibakteri Fraksi Teraktif Daun Pacar Kuku (Lawsonia inermis Linn.) Terhadap Staphylococcus aureus Dan Escherichia coli, Molecule, 8(3): 183.

Hermansyah, M.M., 2015, Ekstraksi Senyawa Fenol dari Batang dan Daun Mangga Menggunakan Pelarut Metanol dengan Metode Maserasi dan Microwave Asissted Extraction (MAE), Tigas Akhir, Program Studi Teknik Kimia Fakultas Teknik Universitas Negeri Semarang.

Marliana, E., dan Saleh, C., 2011, Uji Fitokimia Dan Aktivitas Antibakteri Ekstrak Kasar Etanol, Fraksi n-Heksana, Etil Asetat Dan Metanol Dari Buah Labu Air (Lagenari siceraria (Molina) Standl), 8(2): 65

Ningsih, D.R, Zusfahai, dan Mantari, D., 2017, Ekstrak daun Mangga (Mnagifera indica L.) Sebagai ANtijamur Terhadap Jamur Candida albicans dan Identifikasi Golongan Senyawanya, Jurnal Kimia Riset, 2 (1): 61.

PerkaBPOM, 2014, no 12 tentang Persyaratan Mutu Obat Tradisional

Pramono S., 2002, Kontribusi Bahan Obat Alam Dalam Mengatasi Krisis Bahan Obat Di Indonesia, Jurnal Bahan Alam Indonesia, 1(1):18-19

Puspitasari A.D. dan Pramono S., 2015, Perbandingan Metode Pembuatan Ekstrak Terpurifikasi Bee Propolis Dari Lebah Madu (Apis mellifera) Berdasarkan Kadar Flavonoid Total Dihitung Sevagai Rutin, Trad. Med. J., 20(2): 76-81.

Saifudin A., Rahayu, V. dan Teruna, H.Y., 2011, Standarisasi Bahan Obat Alam, Graha Ilmu, Yogyakarta, 4 
Sumenda L., Rampe, H.L., dan Mantiri, F R., 2011, Analisis Kandungan Klorofil Daun Mangga (Mangifera indica L.) pada Tingkat Perkembangan Daun Yang Berbeda, 1-5

Voight, R., 1994, Teknologi Sediaan Farmasi, Gadjah Mada University Press.

Widyaningtias, N.M.S.R, Yusdiantara, P.S., dan Paramita, N.L.P.V., 2014, Uji Aktivitas Antibakteri Ekstrak Terpurifikasi Daun Sirih Hijau (Piper betle L.) Terhadap Bakteri Propionibacterium acnes

Yulianti, D., Susilo, B. dan Yulianingsih, R., 2014, Pengaruh Lama Ekstraksi dan Konsentrasi Pelarut Etanol Terhadap Sifat Fisika-Kimia Ekstrak Daun Stevia (Stevia rebaudiana Bertoni M.) Dengan Metode Microwave Assited Extraction (MAE), Jurnal Bioproses Komoditas Tropis 